\title{
Patients Hospitalized with pH1N1 Influenza in an Academic Community Medical Center
}

\author{
Hagit Bergman $^{1}$, Lawrence L. Livornese Jr. ${ }^{1}$, Suryaprakash Sambhara ${ }^{2}$, \\ Jerome Santoro ${ }^{1}$ and Scott K. Dessain ${ }^{*} 3$
}

\author{
${ }^{I}$ Department of Medicine, Lankenau Medical Center, Wynnewood, PA 19096, USA \\ ${ }^{2}$ Centers for Disease Control and Prevention, Influenza Division, Atlanta, GA 30333, USA \\ ${ }^{3}$ Lankenau Institute for Medical Research, Wynnewood, PA 19096, USA
}

\begin{abstract}
Background: The emergence of a novel strain of pandemic influenza (pH1N1) in 2009 presented significant challenges to health care facilities worldwide. In our academic community medical center in suburban Philadelphia, we noted our first pH1N1 diagnosis in September 2009. We sought to assess the impact of pH1N1 disease on our hospitalized patient population.

Methods: We prospectively collected clinical and epidemiological data on 29 consecutive patients that were admitted to our hospital with a primary or secondary diagnosis of influenza from October 1-November 30, 2009. Data were obtained through care of the patients and chart review.

Results: Prominent symptoms on admission included fever, hypoxia, cough, myalgias, and diarrhea, with leukocytosis and neutrophilia. Pre-existing medical conditions included asthma, pregnancy, immunosuppressive therapy, and sickle cell disease. All but 5 of the patients were under 60 years of age. Three patients had culture-documented bacterial or mycoplasma infections. All but two of the patients received oseltamivir. Six required admission to the intensive care unit but only one patient died.

Conclusions: Our population of hospitalized patients with novel pH1N1 influenza demonstrated many of the features that have been associated with $\mathrm{pH} 1 \mathrm{~N} 1$ disease in other populations. Most of the patients were women and none of the patients died directly as a complication of influenza. We observed a cluster of patients with a tetrad of features comprising a history of asthma, obesity, female gender, and African-American race. Individuals with this constellation of factors should be specifically targeted for $\mathrm{pH} 1 \mathrm{~N} 1$ vaccination.
\end{abstract}

Keywords: pH1N1 Influenza, neutrophilia, vaccination, immunosuppression, PCR, RIDT.

\section{BACKGROUND}

Infection with influenza viruses can result in diverse clinical manifestations that are affected by the nature of the viral genome and host-specific factors, such as co-morbid conditions and pre-existing immunity. In 2009, an influenza A virus $(\mathrm{pH} 1 \mathrm{~N} 1)$ began circulating that was distinct from prior influenza strains [1-5]. Clinical manifestations of the pH1N1 infection were notable for an increased risk of severe pneumonia in children over age 5 and adults under age 65 [1,6-10]. Among older adults (age $\geq 65$ ), the risk of severe disease was lower than with seasonal influenza. This may be due to weakly protective immunity against the virus obtained during remote exposure to influenza strains similar to pH1N1 [11]. The presenting symptoms of $\mathrm{pH} 1 \mathrm{~N} 1$ were similar to those of seasonal influenza and included fever, cough, sore throat, headache, and myalgias, but with an increased prevalence of gastrointestinal symptoms, especially diarrhea $[2,4,12,13]$.

*Address correspondence to this author at the Lankenau Institute for Medical Research, Wynnewood, PA 19096, USA; Tel: 484-343-1799; Fax: 610-645-4623; E-mail: scott.dessain@gmail.com
The pH1N1 influenza was associated with a wide spectrum of disease intensity [5]. In contrast to the original reports of severe and fatal disease, prospective studies demonstrated seroconversion in asymptomatic or only mildly asymptomatic individuals [14,15]. Many risk factors for severe $\mathrm{pH} 1 \mathrm{~N} 1$ influenza were identified that are similar to the risk factors for severe seasonal influenza. These include asthma, chronic obstructive pulmonary disease, diabetes, neurological disease, cardivascular disease, pregnancy, cancer, kidney disease, sickle cell disease, and immunosuppression [7,9,16-26]. Clinical features that correlated with severe disease included pulmonary infiltrates, hypoxia, shortness of breath, cyanosis, elevated creatinine, and leukopenia [7,9,10,20,27-29]. Worse outcomes were observed in patients if oseltamivir treatment was delayed $[7,20,30]$. The majority of these associations were identified in large epidemiological studies.

In the Fall of 2009, we observed an upsurge of cases that had a clinical and/or laboratory diagnosis of $\mathrm{pH} 1 \mathrm{~N} 1$ and were admitted to our academic community medical center. We conducted a prospective observational study, collecting epidemiological and clinical data on the 29 cases of pH1N1 
admitted to the adult medical service at LMC during October 1 and November 30, 2009.

\section{METHODS}

The setting for the study, the Lankenau Medical Center (LMC), is a 331-bed, academic community hospital situated in Wynnewood, Pennsylvania, a suburb adjacent to Philadelphia. LMC serves a diverse suburban and urban adult patient population from Philadelphia and the neighboring suburbs, but does not serve a substantial inpatient pediatric population. In 2009, LMC had 20,550 hospital discharges. LMC is academically affiliated with the Thomas Jefferson University and has residency and fellowship training programs in medicine and surgery.

The study was conducted over an 8 week period from October 1 to November 30, 2009. Hospitalization was defined as being admitted to the inpatient service for greater than 24 hours. Patients were identified either because they were being cared for by one of the authors of the study (HB, LLL, JS) or because the LMC clinical laboratory reported positive pH1N1 testing results on a hospitalized patient. Subjects were considered suitable for inclusion in our study if they tested positive for the nasopharyngeal swab - rapid influenza diagnostic test (RIDT). Positive influenza A RIDTs were considered indicative of infection with pH1N1, which was the prevalent influenza strain during the study period [31]. Swabs were analyzed at the LMC laboratory. RT-PCR tests were performed by the Bureau of Laboratories, Pennsylvania Department of Health (Exton, PA). Additional subjects were included if considered probable $\mathrm{pH} 1 \mathrm{~N} 1$ infections, in which the clinical suspicion was high, the nasopharyngeal swab was negative, the RTPCR test was not obtained, and no other organism was identified. We collected and analyzed clinical and epidemiological data on a total of 29 patients, using a combination of physician-patient contact and chart review. The study was conducted as a Quality Improvement Initiative, to assess the impact of $\mathrm{pH} 1 \mathrm{Nq}$ influenza on the LMC inpatient population.

\section{RESULTS}

At LMC, the first positive RIDT in an adult $(\geq 18$ years of age) was obtained on August 3, 2009. A total of 4 positive patients were identified in August, 2009, and 11 cases were identified in September, indicating that we were in the early stages of the $2009 \mathrm{pH} 1 \mathrm{~N} 1$ epidemic (Fig. 1). From October 1 to November 30, 2009, we conducted a prospective observational study of patients with a diagnosis of influenza who were admitted to the hospital. In October and November, 2009, 166 and 73 patients tested positive for influenza, respectively (Fig. 1). This was followed by an abrupt drop-off in cases in December, during which we had only 5 positive test results. Thus, the timing of our study coincided with the peak of the 2009 influenza season at LMC.

The characteristics of the patients in our study are given in Table 1. 25 subjects $(86 \%)$ were positive by the RIDT test, and $2(7 \%)$ were negative for the RIDT, but positive by the RT-PCR test. Two additional patients (7\%) were considered highly probable pH1N1 influenza. They were RIDT-negative, but had clinical findings strongly suggestive of influenza, including fever, sore throat, myalgias, and cough. In addition to suspected or RIDT-diagnosed influenza, the admission diagnoses (Fig. 2) included asthma exacerbation (7 [24\%]), pneumonia (7 [24\%]), cardiovascular complications (5 [17\%]) and sickle cell crisis (2, [7\%]). One patient each had a diagnosis of gastrointestinal bleed, diabetic ketoacidosis, diarrhea with dehydration, and systemic inflammatory response syndrome. Patients ranged in age between 19-79 years (mean 47.1 years [median 47 years]) (Fig. 3). Virtually all of the admitted patients were female (25 [86\%]). Sixteen (55\%) were African-American $(\mathrm{n}=16)$. The most common co-morbid condition was obesity (defined as a body mass index (BMI) $>30)$ in $17(59 \%)$. Seven $(24 \%)$ of these patients also met the definition for morbid obesity (BMI $>40)$. Thirteen $(45 \%)$ the patients had asthma and 9 (31\%) smoked tobacco. Three patients were pregnant (26 weeks, 32 weeks, and 1 day post-partum), and two of these had asthma. Two of the patients had sickle cell disease and one was undergoing therapy for breast cancer. Seven of our patients $(24 \%)$ had a tetrad of features: a history of asthma, obesity, female gender, and AfricanAmerican case.

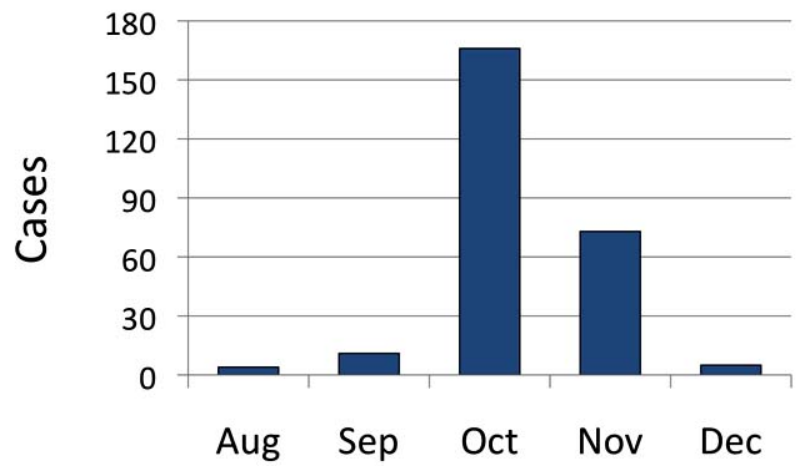

Fig. (1). Positive RIDT results for adult patients (age $>=18$ years of age) at the Lankenau Medical Center, August-December 2009.

Patients presented to the hospital within 1-14 days of their initial symptoms (mean 4.2 days, median 3 days). The symptoms that were typical of those reported by others for pH1N1 influenza include cough (27 [93\%]), shortness of breath $(24[83 \%])$, subjective fever (23 [79\%]), myalgias (19 $[66 \%])$, sore throat $(10[34 \%])$, diarrhea $(7 / 29,24 \%)$, and headache $(6 / 29,21 \%)$. Temperatures on admission ranged from $96.3^{\circ} \mathrm{F}-103.7^{\circ} \mathrm{F}\left(35.7^{\circ} \mathrm{C}-39.8^{\circ} \mathrm{C}\right)$, with a mean temperature of $99.5^{\circ} \mathrm{F}\left(37.5^{\circ} \mathrm{C}\right)$. Chest radiography showed infiltrates suggestive of pneumonia in 10 patients (34\%). Hypoxia, defined as an $\mathrm{O}_{2}$ sat $<93 \%$ in room air or as a requirement for supplemental $\mathrm{O}_{2}$, was observed in 12 patients $(41 \%)$ and in all but one of the patients with lung infiltrates (9 [31\%]). Ten patients (34\%) had leukocytosis $(>10,000)$ with a predominance of neutrophils (44-97\%, mean $76 \%$ ). Additional microbiological isolates were obtained in 3 patients ( 2 with M. pneumoniae, 1 with $P$. aeruginosa).

All but two of the patients received oseltamivir at standard doses (75 mg BID). One of the exceptions 
Table 1. Patient Characteristics

\begin{tabular}{|c|c|}
\hline \multicolumn{2}{|l|}{ Age, Years } \\
\hline Mean (SD) & $47.1(16.6)$ \\
\hline Median (range) & $47(19-79)$ \\
\hline \multicolumn{2}{|l|}{ Gender, n (\%) } \\
\hline Female & $25(86)$ \\
\hline Male & $4(14)$ \\
\hline \multicolumn{2}{|l|}{ Comorbidities, n (\%) } \\
\hline Obesity (BMI > 30) & $17(59)$ \\
\hline Morbid obesity (BMI >40) & $7(24)$ \\
\hline Asthma & $13(45)$ \\
\hline Tobacco use & $9(31)$ \\
\hline Sickle cell disease & $2(6)$ \\
\hline Chemotherapy & $1(3)$ \\
\hline Pregnancy & $3(10)$ \\
\hline \multicolumn{2}{|l|}{ Presenting symptoms, n (\%) } \\
\hline Cough & $27(93)$ \\
\hline Dyspnea & $24(83)$ \\
\hline Subjective fever & $23(79)$ \\
\hline Myalgias & $19(66)$ \\
\hline Sore throat & $10(34)$ \\
\hline Diarrhea & $7(24)$ \\
\hline \multicolumn{2}{|l|}{ Clinical findings } \\
\hline \multicolumn{2}{|l|}{ Temp on arrival to ED } \\
\hline Mean & $99.6^{\circ} \mathrm{F}, 37.6^{\circ} \mathrm{C}$ \\
\hline \multirow[t]{2}{*}{ Median (range) } & $99.5^{\circ} \mathrm{F}\left(96.3^{\circ}-103.7^{\circ} \mathrm{F}\right)$ \\
\hline & $37.5^{\circ} \mathrm{C}\left(35.7^{\circ}-39.8^{\circ} \mathrm{C}\right)$ \\
\hline Hypoxia (O2 sat < 93\%), n (\%) & $12(41)$ \\
\hline Pulmonary infiltrates, n (\%) & $9(31)$ \\
\hline Leukocytosis $(>10,000 / \mu 1), \mathrm{n}(\%)$ & $10(34)$ \\
\hline $\begin{array}{l}\text { Additional diagnosed } \\
\text { infection, } \mathrm{n}(\%)\end{array}$ & $\begin{array}{l}3(10) \\
(2 M . \text { pneumoniae, } 1 \text { P. aeruginosa) }\end{array}$ \\
\hline \multicolumn{2}{|l|}{ Treatment and disposition, $\mathrm{n}(\%)$} \\
\hline Oseltamivir & $27(93)$ \\
\hline ICU & $6(21)$ \\
\hline Death & $1(3)$ \\
\hline Discharge & $28(97)$ \\
\hline
\end{tabular}

presented with renal insufficiency and had $\mathrm{pH} 1 \mathrm{~N} 1$ infection as a secondary diagnosis. The other had an outpatient diagnosis of pH1N1 and received a full course of Tamiflu, but was then admitted with post-influenza pneumonia. Six of the patients $(21 \%)$ were admitted to the ICU and $5(17 \%)$ had pulmonary infiltrates and hypoxia on admission. Both patients with sickle cell disease had pulmonary infiltrates and one required mechanical ventilation in the ICU. Another patient was transferred to the ICU with diabetic ketoacidosis. The one patient who died was admitted to the ICU with disseminated intravascular coagulopathy and a massive gastrointestinal hemorrhage that lead to a pulseless cardiac activity arrest and death. The other patients survived and were eventually discharged to home.

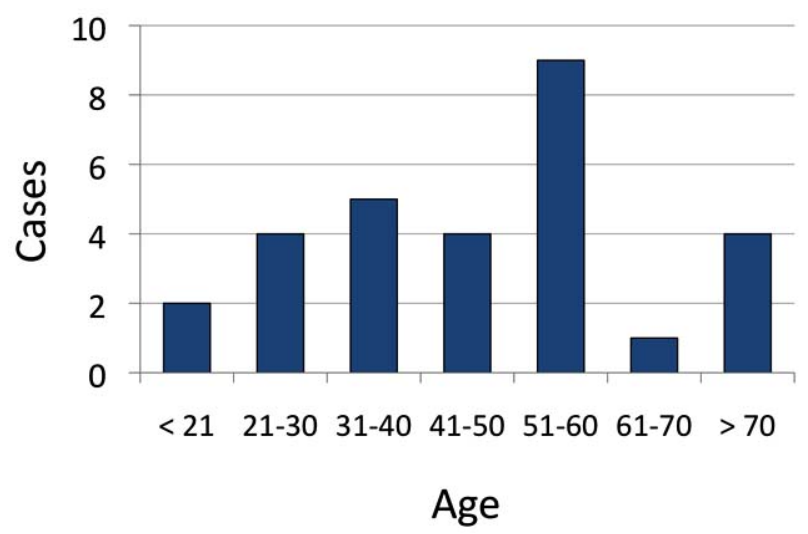

Fig. (2). Ages of the patients admitted to the Lankenau Medical Center with a diagnosis of pH1N1 influenza, October and November, 2009.

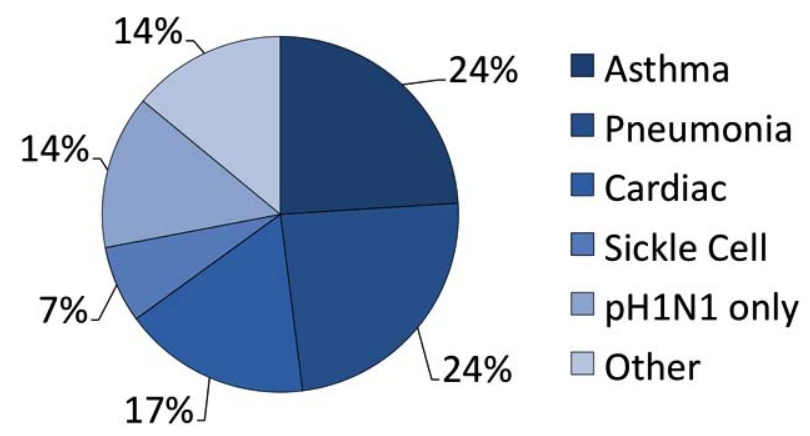

Fig. (3). Primary admission diagnoses of the study population.

\section{DISCUSSION}

We conducted a prospective observational study of cases of pH1N1 influenza admitted to the LMC during the peak of our 2009 epidemic. Studies have been published that describe a diversity of populations affected by the $\mathrm{pH} 1 \mathrm{~N} 1$ influenza outbreak, but ours is the first to focus on an inpatient population at a single North American academic community medical center. The impact of $\mathrm{pH} 1 \mathrm{~N} 1$ influenza on local populations may be distinct due to regional, facilitydependent, and population-specific effects. For instance, indigenous populations in New Zealand and North America $[8,32,33]$ had a disproportionate incidence of severe disease, as did male patients in one study in China [34].

Our study was notable for 7 of the patients presenting with a tetrad of features that comprised a history of asthma, obesity, female gender, and African-American race. Each of the patients with the tetrad had mild-moderate hypoxia, although none of them required transfer to the ICU. Obesity has been associated with severe $\mathrm{pH} 1 \mathrm{~N} 1$ influenza, although it had not previously been linked to complicated seasonal influenza. Asthma has been established as an independent risk factor for complications of seasonal and $\mathrm{pH} 1 \mathrm{~N} 1$ influenza $[3,18,23,25,34-37]$. Female gender and AfricanAmerican race have not independently been associated with higher rates of complications of $\mathrm{pH} 1 \mathrm{~N} 1$, although in one survey of hospital admissions in Wisconsin, African- 
American patients were disproportionately affected by pH1N1 [38].

Our population of hospitalized patients was affected by a broad spectrum of factors that have been associated with severe seasonal and $\mathrm{pH} 1 \mathrm{~N} 1$ influenza, including pregnancy, cardiac disease, renal insufficiency, and cancer therapyrelated immunosuppression. Upon admission, findings of pulmonary infiltrates, diarrhea, and neutrophilia were quite common. Admission temperatures were varied, including mild hypothermia and fevers, but did not correlate with any other clinical variables. Most of the patients were under 60 years of age, consistent with observations in other studies and the finding that many individuals over 60 have a persisting immunoreactivity with $\mathrm{pH} 1 \mathrm{~N} 1$ antigens [11], although our group of 4 patients over 70 was atypical, compared to other studies. Only three of the subjects had an additional microbiological diagnosis. Despite the need for hospitalization, most of the patients were discharged to home, and the only observed death was not directly attributable to influenza.

\section{CONCLUSION}

In summary, our study of patients admitted to our academic medical center with a diagnosis of pH1N1 influenza has identified a novel tetrad of features that may indicate particular susceptibility to severe $\mathrm{pH} 1 \mathrm{~N} 1$ influenza, including a history of asthma, obesity, female gender, and African-American race. Individuals with this constellation of factors should be specifically targeted for $\mathrm{pH} 1 \mathrm{~N} 1$ vaccination.

\section{COMPETING INTERESTS}

The authors declare that they have no competing interests.

\section{AUTHORS' CONTRIBUTIONS}

HB, SS, JS, SKD conceived the study. HB, LLL, JS cared for patients. HB, SS, JS, SKD wrote the paper. All authors read and approved the final manuscript.

\section{HUMAN SUBJECTS}

The study was performed as a Quality Improvement Initiative, which does not require IRB approval in the United States.

\section{ACKNOWLEDGEMENTS}

We are grateful to Olarae Geiger, Eileen O'Rourke and Linda Dey for communication of RIDT test results and Tom McLaughlin for information about LMC admissions.

\section{DISCLAIMER}

The findings and conclusions in this report are those of the authors and do not necessarily represent the views of the funding agency or Centers for Disease Control and Prevention.

\section{ABBREVIATIONS}

$$
\begin{array}{ll}
\text { pH1N1 } & =2009 \text { pandemic H1N1 influenza } \\
\text { RIDT } & =\text { Rapid influenza diagnostic test } \\
\mathrm{O}_{2} & =\text { Oxygen }
\end{array}
$$

\section{REFERENCES}

[1] Chowell G, Bertozzi SM, Colchero MA, et al. Severe respiratory disease concurrent with the circulation of H1N1 influenza. N Engl J Med 2009; 361(7): 674-9.

[2] Dawood FS, Jain S, Finelli L, et al. Emergence of a novel swineorigin influenza A (H1N1) virus in humans. N Engl J Med 2009; 360(25): 2605-15

[3] Louie J, Winter K, Harriman K, et al. Hospitalized patients with novel influenza A (H1N1) virus infection - California, April-May, 2009. MMWR Morb Mortal Wkly Rep 2009; 58(19): 536-41.

[4] Shinde V, Bridges CB, Uyeki TM, et al. Triple-reassortant swine influenza A (H1) in humans in the United States, 2005-2009. N Engl J Med 2009; 360(25): 2616-25.

[5] Bautista E, Chotpitayasunondh T, Gao Z, et al. Clinical aspects of pandemic 2009 influenza A (H1N1) virus infection. N Engl J Med 2010; 362(18): 1708-19.

[6] Dominguez-Cherit G, Lapinsky SE, Macias AE, et al. Critically ill patients with 2009 influenza A(H1N1) in Mexico. JAMA 2009; 302(17): 1880-7.

[7] Jain S, Kamimoto L, Bramley AM, et al. Hospitalized patients with 2009 H1N1 influenza in the United States, April-June 2009. N Engl J Med 2009; 361(20): 1935-44.

[8] Kumar A, Zarychanski R, Pinto R, et al. Critically ill patients with 2009 influenza $\mathrm{A}(\mathrm{H} 1 \mathrm{~N} 1)$ infection in Canada. JAMA 2009; 302(17): 1872-9.

[9] Louie JK, Acosta M, Winter K, et al. Factors associated with death or hospitalization due to pandemic 2009 influenza A(H1N1) infection in California. JAMA 2009; 302(17): 1896-1902.

[10] Perez-Padilla R, de la Rosa-Zamboni D, Ponce de Leon S, et al. Pneumonia and respiratory failure from swine-origin influenza A (H1N1) in Mexico. N Engl J Med 2009; 361(7): 680-9.

[11] CDC. Serum Cross-Reactive Antibody Response to a Novel Influenza A (H1N1) Virus After Vaccination with Seasonal Influenza Vaccine. MMWR Morb Mortal Wkly Rep 2009; 58(19): 521-4.

[12] Chang YS, van Hal SJ, Spencer PM, Gosbell IB, Collett PW. Comparison of adult patients hospitalised with pandemic (H1N1) 2009 influenza and seasonal influenza during the "PROTECT" phase of the pandemic response. Med J Aust 2010; 192(2): 90-3.

[13] Cao B, Li XW, Mao Y, et al. Clinical features of the initial cases of 2009 pandemic influenza A (H1N1) virus infection in China. N Engl J Med 2009; 361(26): 2507-17.

[14] Miller E, Hoschler K, Hardelid P, Stanford E, Andrews N, Zambon M. Incidence of 2009 pandemic influenza A H1N1 infection in England: a cross-sectional serological study. Lancet 2010; 375(9720): 1100-8.

[15] Hien TT, Boni MF, Bryant JE, et al. Early pandemic influenza (2009 H1N1) in Ho Chi Minh City, Vietnam: a clinical virological and epidemiological analysis. PLoS Med 2010; 7(5): e1000277.

[16] WHO. Fact Sheet: Influenza (Seasonal). http://wwwwhoint/media centre/factsheets/fs211/en/indexhtml 2009.

[17] Thompson WW, Shay DK, Weintraub E, et al. Influenza-associated hospitalizations in the United States. JAMA 2004; 292(11): 133340 .

[18] Subramony H, Lai FY, Ang LW, Cutter JL, Lim PL, James L. An epidemiological study of 1348 cases of pandemic H1N1 influenza admitted to Singapore Hospitals from July to September 2009. Ann Acad Med Singapore 2010; 39(4): 283-8.

[19] Jamieson DJ, Honein MA, Rasmussen SA, et al. H1N1 2009 influenza virus infection during pregnancy in the USA. Lancet 2009; 374(9688): 451-8

[20] Slopen ME, Mosquera MC, Balter S, et al. Patients hospitalized with 2009 pandemic influenza A (H1N1) - New York City, May 2009. MMWR Morb Mortal Wkly Rep 2010; 58(51): 1436-40.

[21] van't Klooster TM, Wielders CC, Donker T, et al. Surveillance of hospitalisations for 2009 pandemic influenza $\mathrm{A}(\mathrm{H} 1 \mathrm{~N} 1)$ in the Netherlands, 5 June - 31 December 2009. Euro Surveill 2010; 15(2): 19461.

[22] Siston AM, Rasmussen SA, Honein MA, et al. Pandemic 2009 influenza $\mathrm{A}(\mathrm{H} 1 \mathrm{~N} 1)$ virus illness among pregnant women in the United States. JAMA 2010; 303(15): 1517-25.

[23] Fuhrman C, Bonmarin I, Paty AC, et al. Severe hospitalised 2009 pandemic influenza $\mathrm{A}(\mathrm{H} 1 \mathrm{~N} 1)$ cases in France, 1 July-15 November 2009. Euro Surveill 2010; 15(2): 19463.

[24] Efstathiou P, Tseroni M, Baka A, et al. Deaths and hospitalizations related to 2009 pandemic influenza A (H1N1) - Greece, May 2009- 
February 2010. MMWR Morb Mortal Wkly Rep 2010; 59(22): 682-6.

[25] Dee S, Jayathissa S. Clinical and epidemiological characteristics of the hospitalised patients due to pandemic H1N1 2009 viral infection: experience at Hutt Hospital, New Zealand. N Z Med J 2010; 123(1312): 45-53.

[26] Inusa B, Zuckerman M, Gadong N, et al. Pandemic influenza A (H1N1) virus infections in children with sickle cell disease. Blood 2010; 115(11): 2329-30.

[27] Echevarria-Zuno S, Mejia-Arangure JM, Mar-Obeso AJ, et al. Infection and death from influenza A H1N1 virus in Mexico: a retrospective analysis. Lancet 2009; 374(9707): 2072-9.

[28] Denholm JT, Gordon CL, Johnson PD, et al. Hospitalised adult patients with pandemic (H1N1) 2009 influenza in Melbourne, Australia. Med J Aust 2010; 192(2): 84-6.

[29] Zarychanski R, Stuart TL, Kumar A, et al. Correlates of severe disease in patients with 2009 pandemic influenza (H1N1) virus infection. CMAJ 2010; 182(3): 257-64.

[30] Dubar G, Azria E, Tesniere A, et al. French experience of 2009 $\mathrm{A} / \mathrm{H} 1 \mathrm{~N} 1 \mathrm{v}$ influenza in pregnant women. PLoS One 2010; 5(10): e13112.

[31] CDC. Interim recommendations for clinical use of influenza diagnostic tests during the 2009-10 influenza season. http://www. cdc.gov/h1n1flu/guidance/diagnostic_tests.htm; (September 29, 2009).
[32] Verrall A, Norton K, Rooker S, et al. Hospitalizations for pandemic (H1N1) 2009 among Maori and Pacific Islanders, New Zealand. Emerg Infect Dis 2010; 16(1): 100-2.

[33] CDC. Deaths related to 2009 pandemic influenza A (H1N1) among American Indian/Alaska Natives - 12 states, 2009. MMWR Morb Mortal Wkly Rep 2009; 58(48): 1341-4.

[34] Cui W, Zhao H, Lu X, et al. Factors associated with death in hospitalized pneumonia patients with $2009 \mathrm{H} 1 \mathrm{~N} 1$ influenza in Shenyang, China. BMC Infect Dis 2010; 10: 145.

[35] Lee EH, Wu C, Lee EU, et al. Fatalities associated with the 2009 H1N1 influenza A virus in New York city. Clin Infect Dis 2010; 50(11): 1498-504.

[36] Napolitano LM, Park PK, Sihler KC, et al. Intensive-care patients with severe novel influenza A (H1N1) virus infection - Michigan, June 2009. MMWR Morb Mortal Wkly Rep 2009; 58(27): 749-52.

[37] Morgan OW, Bramley A, Fowlkes A, et al. Morbid obesity as a risk factor for hospitalization and death due to 2009 pandemic influenza A(H1N1) disease. PLoS ONE 2010; 5(3): e9694.

[38] Chitnis AS, Truelove SA, Druckenmiller JK, Heffernan RT, Davis JP. Epidemiologic and clinical features among patients hospitalized in Wisconsin with $2009 \mathrm{H} 1 \mathrm{~N} 1$ influenza A virus infections, April to August 2009. WMJ 2010; 109(4): 201-8.

(C) Bergman et al.; Licensee Bentham Open.

This is an open access article licensed under the terms of the Creative Commons Attribution Non-Commercial License (http://creativecommons.org/licenses/ by-nc/3.0/) which permits unrestricted, non-commercial use, distribution and reproduction in any medium, provided the work is properly cited. 